\title{
LACUSTRINE ORGANIC FLUXES AND PALAEOCLIMATIC VARIATIONS DURING THE LAST 15 ka: LAC DU BOUCHET (MASSIF CENTRAL, FRANCE)
}

\author{
A. SIFEDDINE*†, P. BERTRAND**, E. LALLIER-VERGÈS* and A.J. PATIENCE \\ *GdR 942, URA 724-CNRS, Sédimentation et Diagenèse Organique, Université d'Orléans, BP 6759 45067, \\ Orléans Cx 2, France \\ $\dagger$ Present address: ORSTOM, UR12, AIMPACT, 32 Av. Henri Varagnat, 93143 Bondy, France \\ $\ddagger$ Present address: URA 197, CNRS, Universite Bordeaux I, 33405 Talence, France
}

\begin{abstract}
To assess the influence of climatic changes on organic lacustrine sedimentation, two cores recovered from the centre of the Lac du Bouchet were studied by petrographical (palynofacies) and geochemical methods. Only core LDB H was used for estimation of the organic fluxes. The variation of these fluxes with climo-stratigraphic periods showed: low organic fluxes during the Lateglacial, an increase at the beginning of the Holocene, a minimum at the end of the Atlantic period resulting from the climatic cooling, and a maximum at the end of the Sub-Boreal related to the installation of the present climatic conditions. Copyright $(C) 1996$ Elsevier Science Ltd
\end{abstract}

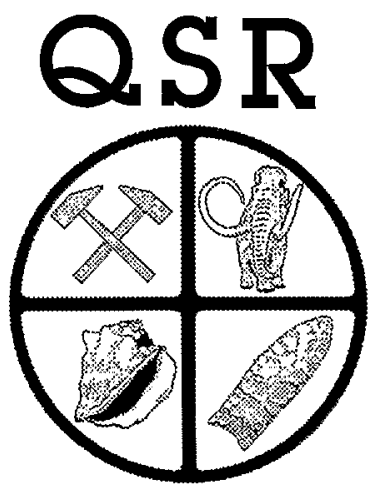

\section{INTRODUCTION}

Pollen in sediments record the large changes in the evolution of vegetation on a regional scale. Microorganisms however, record the physico-chemical conditions in the aquatic and sedimentary environments. The organic and mineral constituents record local phenomena on the scale of the surrounding basin and the lake itself. Thus the sedimentary record contains information which reflects both the regional climatic and also the proximal conditions of the surrounding basin.

To improve the palaeo-environmental reconstruction using the sediment record, the sequence must be as continuous as possible. The morphology and the depth of maar lakes allow them to accumulate sediments rapidly and continuously allowing sufficient resolution for the study of the time periods involved. More generally, the elevated situation of these lakes allows them to escape the influences of the local geomorphological evolution which, as seen on the plains, would tend to dilute the sedimentary markers. Thus, maar lakes constitute an interesting example for the study of sedimentary variations linked to climatic changes.

The Lac du Bouchet is a maar crater lake situated in the southern and highest section of the Devès plateau (1200 m altitude), $15 \mathrm{~km}$ southwest of Cayres (Massif Centräl, Haute Loire, France) (Fig. 1). It occupies an ancient volcanic sub-circular crater some $800 \mathrm{~m}$ in diameter with a water depth of $28 \mathrm{~m}$. The surrounding basin, which is twice the diameter of the lake itself, is composed of volcanic tuffs and lava flows. The Lac du Bouchet is the only maar lake in the Devès plateau which presents a relatively constant sedimentary sequence over the last $120 \mathrm{ka}$. Previous palynological, palaeomagnetic and diatom studies (Reille and de Beaulieu, 1990; Sifeddine et al., 1992; Thouveny et al., 1990; and Pailles, 1989 respectively) on cores recovered from the lake provide a good knowledge of the climatic variations over this time interval. This study concerns cores LDB X and LDB $\mathrm{H}$ recovered from the centre of the Lac du Bouchet, of which detailed sedimentological studies are presented in Lallier-Vergès et al. (1993). However, the general characteristics of the cores are given below.

The visual description of cores $\mathrm{LDB} \mathrm{H}$ and $\mathrm{LDB}$ $\mathrm{X}$ showed five units with differing thicknesses in each core. Unit V (at the base) is a silty clay with several turbiditic beds rich in detrital elements. This unit is topped by a level several centimeters thick whose colour and texture change progressively into a blackish laminated level (unit IV). The thickness of unit IV is condensed to $10 \mathrm{~cm}$ in core LDB $\mathrm{H}$ in comparison to its thickness of $30 \mathrm{~cm}$ in core LDB X. Unit III is an organic clay differentiated into two sub-units in core 


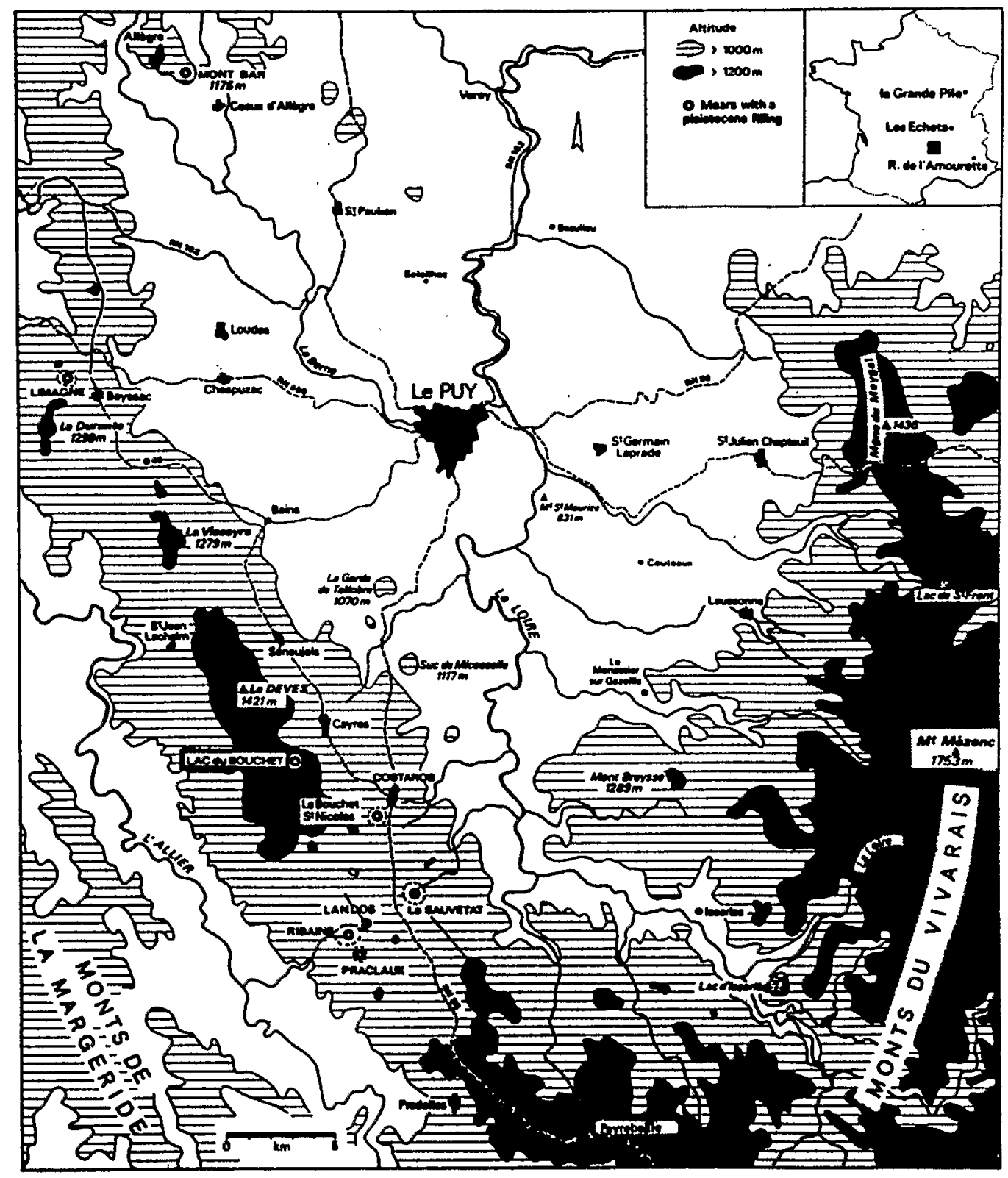

FIG. 1. Location map of Lac du Bouchet (after Reille and de Beaulieu, 1988).

LDB X: a laminated silty sub-unit (IIIA) which contains vegetal debris overlain by a sediment composed of highly organic silts (sub-unit IIIB). In core LDB $\mathrm{H}$, sub-unit IIIA is absent. Unit II contains intercalated dark and light bands of silt and organic rich matter. Finally, unit 1 is a homogenous reddish brown clay-silt which lacks any stratification. Its homogeneity perhaps results from the establishment of a benthic fauna associated with the oxygenation of the bottom waters, due to circulation of the lake waters (Casta, 1991).

\section{ORGANIC MATTER CHARACTERISTICS}

Rock eval pyrolisis was completed at the University of Orléans and give the following parameters: total organic carbon (TOC) expressed as percent dry weight of the total sediment, and hydrogen index (HI- mg HC/g TOC) which represents the quantity of hydrocarbons (mg) liberated per gram of organic carbon during pyrolisis with an inert gas. Lallier-Vergès et al. (1993) showed important variations in TOC and HI which reflect the sedimentary units (Fig. 2 ). The values of TOC are low (below 1\%) in unit V, they increase in unit IV (to around 10\%) and reach their maximum in unit II (15-30\%). Core LDB X shows a peak of TOC in unit IIIB corresponding to a carpet of vegetal fibers (fontinalis). The values of TOC decrease in unit II and stabilise in unit I (10\%). All values of HI display the same evolution to those of TOC. They increase from unit $\mathrm{V}$ until unit IIB where they attain a maximum of 500 , after which they decrease and stabilise in unit I to around 300. In core LDB $H$ these values reach a maximum of 800 in unit II.

Optical study of the isolated organic matter after acid attack (HG-HF) allowed the characterisation of the major organic constituents (palynofacies). Variations 
LDB X

LDB H

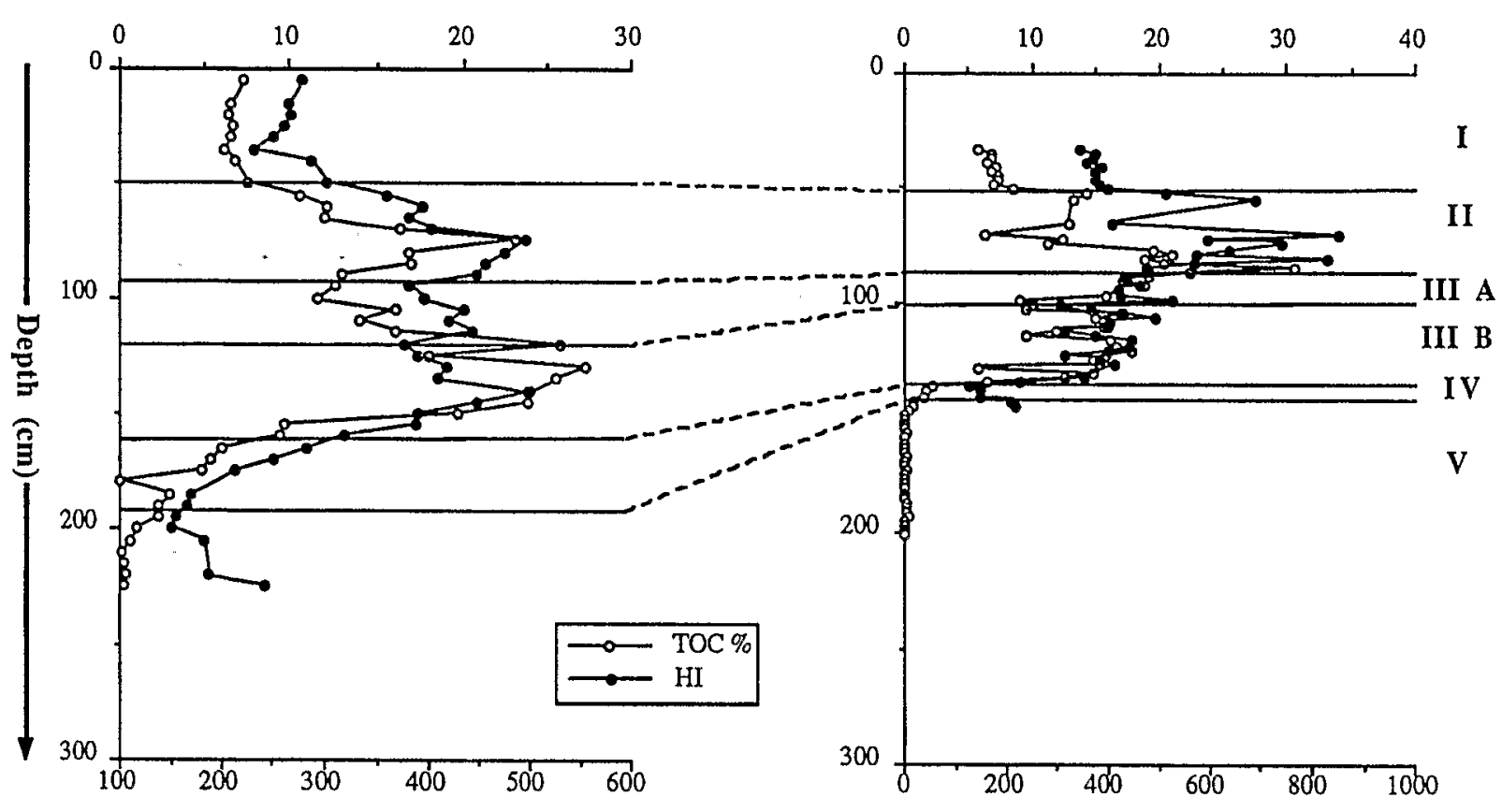

FIG. 2. Variation of Total Organic Carbon (TOC) and Hydrogen Index (HI) in cores LDB X and LDB H (after LallierVergès et al., 1993).

were observed in the following organic fractions: translucid ligno-cellulosic debris, opaque ligno-cellulosic debris, cuticle membranes, spores and pollen, carbonised debris (pyrofusinite), pedogenetic amorphous organic matter (corresponding to reddish brown amorphous organic material present in abundance in the palynofacies of the soil derived from the surrounding basin and thus confirming the pedogenetic origin of this material), and the greyish amorphous organic matter. The variation of these fractions with depth (Fig. 3) is described below.

Unit $\mathrm{V}$ is characterised by the presence of an organic matter dominated by opaque (oxidised) lignocellulosic debris (LCO); unit IV is marked by an increase in the proportions of greyish amorphous organic matter (G$\mathrm{AOM}$ ) and by the appearance of the reddish amorphous organic matter (R-AOM), translucid ligno-cellulosic debris (LCT), cuticle membranes, spores and pollen. These fractions vary differently throughout units IV, III, II and I; unit $\mathrm{I}$ is differentiated from the others by the presence and abundance of carbonised debris (evidence of vegetation fires). Core LDB $X$ is characterised by the great abundance, in unit $\mathrm{ITB}$, of Fontinalis fibers.

The large variations in the thickness of the sedimentary units observed in both cores and the large disparity in the results between the two cores suggest a non-uniform depositional system (lenticular) in the lake.

\section{RESULTS}

\section{Evaluation of the Organic Fluxes}

Only core LDB-H was used in the flux calculations and, as a result of the lack of water content and sediment density results below $10 \mathrm{~m}$, calculation of these fluxes was limited to the interval corresponding to the last $30 \mathrm{ka}$ in core LDB H (Sifeddine et al., 1995). The stratigraphy was developed using a combination of palynology (Lallier-Vergès et al., 1993; Reille and de Beaulieu, 1988, 1990), magnetic susceptibility (Thouveny et al., 1990, 1994), palynofacies (organic matter type and quantity) and the organic geochemistry (Bertrand et al., 1992; Lallier-Vergès et al., 1993). Using this age model, the average sedimentary fluxes (calculated using Eqn (1)) were determined for organic carbon and the mineral fraction $\left(\mathrm{g} \cdot \mathrm{cm}^{-2} \cdot \mathrm{an}^{-1}\right)$. These fluxes represent the input of each constituent independent of any dilution effects.

$$
\begin{aligned}
& \text { Sediment Flux }=\text { element concentration } \\
& \times \text { sediment density }\left(\mathrm{g} . \mathrm{cm}^{-3}\right) \\
& \times \text { sedimentation rate }(\mathrm{cm} / \text { year }) .
\end{aligned}
$$

Following the assumption that the quantity of organic carbon in both the autochthonous (greyish amorphous organic matter) and allochthonous (translucid lignocellulosic debris, opaque lignocellulosic debris, cuticle membranes, pedogenetic amorphous organic matter) fractions are the same, the autochthonous and allochtho- 

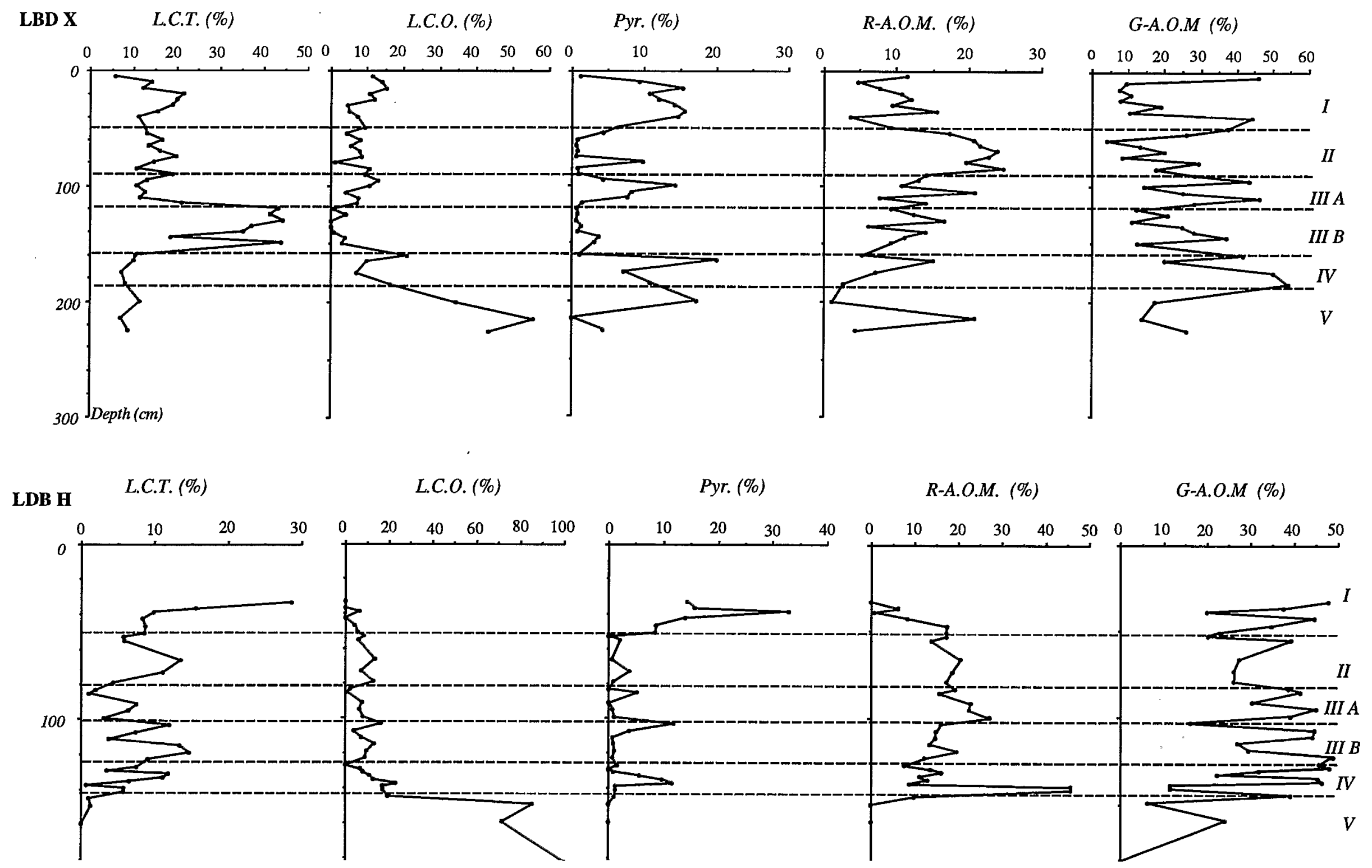

FIG. 3. Variation of organic constituents (palynofacies) in cores LDB X and LDB H. LCT translucid ligno-cellulosic: debris, LCO—opaque ligno-cellulosic debris, Pyr-carbonised debris (Pyrofusinite), R-AOM—reddish amorphous organic material, G-AOM-greyish amorphous organic material. 
nous organic carbon fluxes calculated. The vertical variation of these fluxes (Fig. 4) shows the following evolution: an overall increase in the Boreal, a progressive increase from the Boreal to the Atlantic periods with a drop in these fluxes at the end of this episode, an increase at the beginning of the Sub-Boreal which reaches until a maximum between the end of this period and the beginning of the Sub-Atlantic. The maximum flux of the autochthonous fraction in the Sub-Atlantic is the result of anthropogenic action.

\section{Interpretation and Comparison with Palynological Results}

During the last glacial episode (30,000-13,000 BP), the organic matter was low in abundance and was composed principally of opaque ligno-cellulosic debris which results from oxidative degradation. The large mineral fluxes and the silty nature of the sediment suggest an intense erosion of the surrounding basin due to a weak vegetal cover. Moreover, during this period, the pollen records (Gramineae, Artemisia and Pinus) are characteristic of a steppe developed under a cool regional climate.

In core LDB $\mathrm{H}$ the Older-Dryas, Bölling-Alleröd, Younger-Dryas and the Pre-Boreal are absent. However, as these periods are present in other cores, it is probable that this hiatus is due to lenticular deposition which results in a non-uniform sedimentation in the lake.

The Boreal (9000-8000 BP) is characterised in the pollen records by the development of Corylus and Quercus forests (Reille and de Beaulieu, 1988, 1990), and is recorded in the sediment by the following:

(1) A decrease in the mineral fluxes resulting from a decrease in the erosion of the surrounding basin which is protected by the development of the vegetation.

(2) The improvement of the quality of the organic material (increase in the $\mathrm{HI}$ ) which can be equally well observed by the study of the palynofacies which show an increase in the proportions of greyish amorphous organic material (the residual phytoplanktonic fraction), and reddish amorphous pedogenetic fraction at the expense of the opaque lignocellulosic debris.

(3) An increase in the total organic carbon fluxes.

The increase in the autochthonous organic fraction represented by greyish amorphous organic material (resulting from lacustrine planktonic productivity), is favoured by the input of nutrient elements during the transitional erosive phases of the surrounding basin and is interpreted as a quasi-instantaneous response of the lake to changes in the regional climatic conditions. The allochthonous organic flux (R-OAM) is, however, interpreted as originating from the surrounding basin but with a certain time-lag in reponse to the climatic amelioration (slower installation of the vegetation in the surrounding basin).

The Atlantic (8000-4700 BP) is marked in the pollen records by a forestation (Quercus-Tilia) period which indicates a warm and wet climate. This is translated in the organic sedimentation by moderately high total organic fluxes and by an organic material dominated by pedogenetic reddish amorphous organic matter (allochthonous). At the beginning of the Atlantic, the allochthonous and autochthonous organic fluxes increased progressively, before decreasing towards the end of this period due to a climate cooling marked by the relatively intense development of Fagus-Abies compared to Quercus-Tilia. This cooling decreased the productivity in the lake because of the drop in temperature. The progressive decrease in the percentages of aquatic plant (Isoëtes) pollen is interpreted as an deplenishment of the lake waters in nutrients. This observation is in agreement with the weak mineral fluxes and it is therefore probable that, despite this cooling, the vegetation continued to flourish causing the decrease in the erosion of the surrounding basin and, therefore, the mineral fluxes.

In the Sub-Boreal (4700-2600 BP) the cooling which commenced at the beginning of the Atlantic, continued as indicated by the maximum development of the forest (Fagus) (Lallier-Vergès et al., 1993). The organic sedimentation is characterised by the progressive increase in the organic carbon flux and by the increase of the flux of autochthonous organic material indicating the maximum development of the vegetation in the surrounding basin which stabilised the soil and minimised erosion. The low autochthonous organic fluxes can be explained by a weak lacustrine productivity.

The end of the Sub-Boreal and especially the beginning of the Sub-Atlantic (2600 BP to recent) are characterised by maximum organic carbon fluxes, and by the abundance of the allochthonous organic fractions with high $\mathrm{HI}$ values (i.e. pedogenetic reddish amorphous organic material). This maximum organic carbon flux was probably caused by the maximum development of the soil in the surrounding basin and, in addition, by an intensification of the erosion indicated by the simultaneous increase in the mineral fluxes. This erosion was very probably caused by the installation of the recent climatic conditions approximately $2600 \mathrm{BP}$ (warming and development of less dense vegetation). This modification of the vegetation is recognised in the pollen records by the decrease in the percentages of the Fagus-Quercus pollen and an increase in the Pinus pollen (Reille and de Beaulieu, 1988; Lallier-Vergès et al., 1993) and is connected with an anthropogenic action. Around the middle of the Sub-Atlantic, the surrounding basin was affected by the anthropogenic activity marked in the pollen records by the appearance of cereal species and by Betula which pioneered the ground which was cleared by the forest fires, recorded in the palynofacies by the presence of carbonised debris (pyrofusinite). The progressive increase in the average sedimentary fluxes proves the intensification of the erosion of the surrounding basin encouraged by the clearing of the forests. The progressive increase in the pollen of marginal aquatic plants (Isoëtes), and the maximum autochthonous organic 


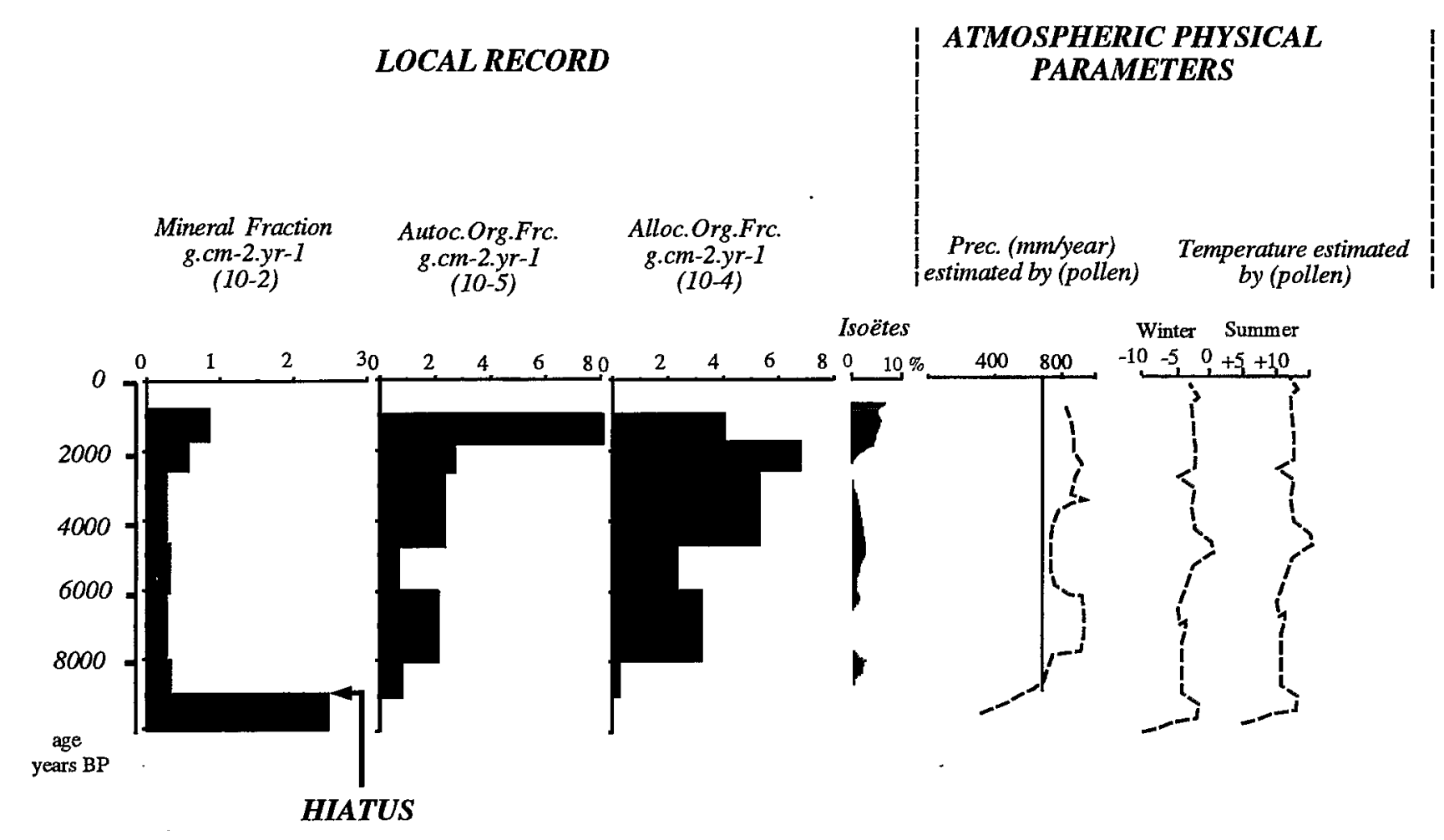
Anthropogenic action

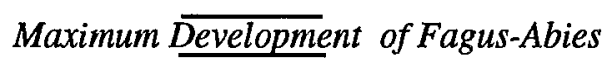
Development of Fagus-Abies
Maximum Development of Quercus-Tilia
Development of Corylus-Quercus

FIG. 4. Comparison between the local record, regional record and physical parameters of the atmosphere in the lac du Bouchet. Autoc. Org. Frc.- autochthonous organic fraction, Alloc. Org. Frc. - allochthonous organic fraction, prec.--precipitation. 
flux (increased production in the lake) during the SubAtlantic might be interpreted as an enrichment of nutrients in the lake waters (Schmid, 1980; Gasse, 1969), which agrees with the intensification of the erosion.

\section{DISCUSSION AND CONCLUSIONS}

The above results analysed using principal component analysis (Table 1) of the organic carbon fluxes and mineral fraction (core LDB $\mathrm{H}$ ), allowed the following general interpretations.

The organic material is principally of detrital origin. The detrital organic flux evolves with the installation of vegetation in the surrounding basin favoured by the climatic amelioration.

The organic fraction of 'planktonic' origin, is rarely the largest fraction and its flux depends essentially on the inputs of the mineral phases carried into the lake during the erosive transitional periods and by the washing of the soils from the surrounding basin during the warm and wet climatic periods. These surges sporadically enrich the lake waters with nutrients which are generally oligotrophic.

During the climatic amelioration of the Boreal (an increase in annual precipitation to around $800 \mathrm{~mm} \mathrm{a}^{-1}$ and an average increase in the temperature to approximately $12^{\circ} \mathrm{C}$ as shown by Guiot et al. (1989)), the important increase of the mineral fractions indicate an enrichment of mineral salts in the lake waters. The lake waters, which became more productive, favoured the increase in the flux of the planktonic (autochthonous) fraction and, the development of aquatic plants (Isoëtes). The maximum warming of the Atlantic period (rainfall: $900 \mathrm{~mm} \mathrm{a}^{-1}$, average temperature around $12^{\circ} \mathrm{C}$ ) resulted in the maximum development of a forest which reduced the general erosion and favoured the pedogenetic dissolution of the nutrient elements under the vegetal cover. Following this dissolution, the runoff waters became enriched in mineral phases. At the end of the Atlantic, the fluxes of the autochthonous organic fraction and the percentages of pollens from aquatic plants decreased due to a cooling (decrease in average temperature from $12^{\circ} \mathrm{C}$ to $10^{\circ} \mathrm{C}$ and reduced rainfall)(Guiot et al., 1989). This atmospheric situation continued until the end of the Sub-Boreal when one notes an increase in the flux of the allochthonous fraction coincident with the maximum development of the vegetation in the surrounding basin. It is around the middle of the Sub-Atlantic that the fluxes of the autochthonous fraction reached their maximum, very probably closely associated with the anthropisation (deforestation) which caused greater erosion. This erosion caused greater productivity in the lake waters (Schmid, 1980; Pailles, 1989).

The results obtained on the hydrology of the lake (Nolden and Nolden, 1988; Truze, 1990) and the ideas developed concerning its circulation (Bonifay and Truze, 1991), suggest that the lake's water level has remained constant since the Eemien and that this stability was controlled by an equilibrium between the storage and outlet of the subterranean waters. If such subterranean sources really do exist, how can one explain the present oligotrophy in the lake (Nolden and Nolden, 1988; Jézéquel et al., 1995). Indeed, the waters which drain the granitic formations and the basaltic basement of the surrounding basin should contain greater concentrations of mineral elements than they presently contain.

If one accepts the hypothesis of the control by subterranean circulations then during a low point in the level of the lake, the neighbouring phreatic nappes, equilibrate the level via the subterranean waters which are richer in mineral elements than the meteoric waters. The lake waters are thus found enriched in nutritic elements favouring increased lacustrine productivity. But this contradicts the results obtained, since it is during the wettest phases that the productivity appears to be favoured.

The field work of Jézéquel et al. (1995) rejects the hypothesis of a subterranean circulatory system, and shows that the lake du Bouchet behaves above all as a natural pluviometer. At the moment, this hypothesis, in combination with that of the believed pedogenetic solubilisation in the soil of the surrounding basin during the hot and wet periods, appears the most likely to explain the variations in the trophic conditions of the lake du Bouchet.

The quality and quantity of the organic material are very susceptible to changes in the climatic palaeoenvironment. This organic matter is composed of two main parts: an allochthonous fraction whose flux depends on the vegetation in the surrounding basin; and an autochthonous fraction whose preservation depends on the physico-chemical conditions during sedimentation and whose flux is directly influenced by the physical conditions in the lacustrine environment (Patience et al., 1996), or indirectly by the conditions in the surrounding basin. Indeed, during the glacial phases, the organic

TABLE 1. Principal component analysis

\begin{tabular}{lllll}
\hline & Mineral Fraction & T.O.C. & Alloch. Org. Fr. & Autoch. Org. Fr. \\
Mineral Fraction & 1 & & & \\
T.O.C. & 0.91306 & 1 & 1 & \\
Alloch. Org. Fr. & 0.9158 & 0.96607 & 0.99878 & 1 \\
\hline Autoch. Org. Fr. & 0.90804 & 0.95906 & & \\
\hline
\end{tabular}


matter is low in abundance, appears degraded and is mainly composed of allochthonous material in contrast to the wet phases when the organic matter is well preserved and the fluxes are relatively large. Thus, the evolution of the organic parameters allows the completion, in the continental domain, of the palaeoclimatic interpretation from traditional markers (e.g. palynology, mineralogy, micropalaeontology). Moreover, it may allow the development of a quantitative palaeoenvironmental marker based on the evaluation of the different organic fluxes, (autochthonous and allochthonous).

Following these interpretations, the main conclusions are as follows.

(1) The last glacial maximum is characterised by a dominant mineral sedimentation.

(2) The climatic amelioration around $15,000 \mathrm{BP}$ is not detected in core LDB $\mathrm{H}$ because of a specific hiatus between the last glacial maximum and the Holocene in this core confirming the heterogeneity of depositional conditions in Lac du Bouchet.

(3) The organic sedimentation in the Holocene is relatively intense compared to older sediments from the lake but is still weak when compared to other crater lake sediments. Generally the climate is humid with a short cool and dry episode around the end of the Atlantic period, the duration of which is uncertain. This short event is probably due to a climatic anomaly of the global system rather than a regional effect because in the other regions of the world (especially in the tropical and sub-tropical zones) one observes different climatic perturbations which are synchronous with this event (Sifeddine, 1991; Sifeddine et al., 1994),

(4) The recent (actual) climatic conditions begin around $2600 \mathrm{BP}$.

(5) The anthropisation of the surrounding basin becomes obvious in the middle of the Sub-Atlantic.

\section{ACKNOWLEDGEMENTS}

The authors would like to thank the Research Group GdR 942 of CNRS at Orléans and Orsay Universities, IFP, CFP-TOTAL, and ELF-Aquitaine who funded this work. We also thank the EU for funding the EUROMAARS and EPOCH programs which financed the work both in the field (coring) and in the laboratories. Special thanks are due to Eugene Bonifay for access to the cores, Jean Louis de Beaulieu for reviewing this paper.

\section{REFERENCES}

Bertrand, P., Brocero, S., Lallier-Vèrgès, E., Tribovillard, N. and Bonifay, E. (1992). Sédimentation organique lacustre et paléoclimats du Pléistocène aux moyennes latitudes: exemple du Lac du Bouchet, Haute Loire, France (résultats préliminaires). Bulletin of the Society Géologie France, 163, 427-433.

Bonifay, E. and Truze, E. (1991). Histoire géologique du Lac du Bouchet. Doc. C.E.R.L.A.T, mém, 2, 15-34.
Casta, L. (1991). Lac du Bouchet: les structures thermométriques et pHmétriques: mise en oeuvre, implications hydrologiques, climatiques, et sédimentologiques. Doc. C.E.R.LAT., mém, 2, 97-111.

Gasse, F. (1969). Les sédiments à diatomées du lac Pavin (Auvergne). Annales de la Station Biologique de Besse-enChansesse, 4, 221-237.

Guiot, L., Pons, A., Beaulieu, J.L. de and Reille, M. (1989). A 140,000 years continental climate reconstruction from two Europeen pollen records. Nature, 338, 309-313.

Jézéquel, D., Albéric, P., Desprairies, A., Eurard, Lavergue, D., Michard, G., Patience, A., Pepe, H., Sarazin, G., Tribouillard, N.P. and Viollier, E. (1995). Geochemical study of the Lac du Bouchet (Haute-Loine, France) Part II: Watersediments-organic matter interacting during the last 2500 years. In: Lallier-Verges, E., Tribouillard, N. and Bertrand, P. (eds), Organic Matter Accumulation: The Organic Cyclicities of the Kint-miridge Clay Formation (Yorkshire, G.B.) and the Recent Maar Sediments (Lac du Bouchet). Lecture Notes in Earth Sciences, 57, 119-143. Springer, Heidelberg.

Lallier-Vergès, E., Sifeddine, A., Beaulieu, J.L. de, Reille, M., Tribovillard, N., Bertrand, P., Mongenot, T., Thouveny, N., Disnar, J.R. and Guillet, B. (1993). Sensibilité de la sédimentation organique aux variations climatiques $\mathrm{du}$ Tardi-Würm et de l'Holocène-le Lac du Bouchet (Haute Loire, France), Bulletin of the Society Geologie France, 164, 661-673.

Nolden, G. and Nolden, M. (1988). Lac du Bouchet: Results of two investigations, phytoplankton and zooplankton. Communication au Colloque du Puy en Velay. 4-5-6 Mai 1988.

Pailles, C. (1989). Les diatomées du lac de maar du bouchet (Massif-Central, France) reconstruction des paléoenvironnement au cours des 120 derniers millénaires. Ph.D. (Thèse de doctorat en Sciences, Univ. Aix-Marseille H). 272 pp.

Patience, A., Lallier-Vergès, E., Albéric, P., Tribovillard, N.P. and Desprairies, A. (1996). Relationships between organomaterial supply and early diagenesis in the lacustrine Environment: a study of surficial sediments from the Lac du Bouchet (Haute-Loire, France). Quaternary Science Reviews, 15, 213-221.

Reille, M. and de Beaulieu, L. (1988). History of the Würm and Holocene vegetation in western Velay (Massif Central, France): A comparison of pollen analysis from three corings at Lac du Bouchet. Review of Palaeobotany and Palynology, 54, 233-248.

Reille, M. and de Beaulieu J.L. (1990). Pollen analysis of a long Pleistocene continental sequence in a Velay maar (Massif Central, France). Palaeogeography, Palaeoclimatology, Palaeoecology, 80, 35-48.

Schmid, A.M.M. (1980). Valve morphogenesis in diatoms. Nova Hedwigia, 23, 811-846.

Sifeddine, A., Bertrand, P., Lallier-Vergès, E. and Patience, A.J. (1995). Organic sedimentation and its relationship with palaeoenvironmental changes over the last 30,000 years (Lac du Bouchet; Hte Loire, France). Comparison with other palaeoclimatic lacustrine examples). In: Lallier-Vergés, E., Tribovillard, N. and Bertrand, P. (eds), Organic Matter Accumulation: The Organic Cyclicities of the Kimmeridge Clay Formation (Yorkshire, G.B.) and the Recent Maar Sediments (Lac du Bouchet). Lecture Notes in Earth Sciences, 57, 157-168. Springer, Heidelberg.

Sifeddine, A. (1991). Sédimentation en milieu lacsutre relation avec les changements de l'environnement climatique au cours des 60,000 dernières années. Ph.D. (Thèse du Muséum d'Histoire Naturelle, Paris). 129 pp.

Sifeddine, A., Lallier-Vergès, E., Bertrand, R, Beaulieu, J.L. de and Reille, M. (1992). Palynofaciès et flux de carbone organique au cours des 30,000 demières années: le Lac du Bouchet (Haute Loire, France). '8th International Palynological Congress', Aix en Provence, 6-12 September 1992. 
Sifeddine, A., Bertrand, P., Fournier, M., Martin, L., Servant, M., Soubiès, F., Suguio, K. and Turcq, B. (1994). La sédimentation organique lacustre en milieu tropical humide (Carajas, Amazonie oriéntale, Brésil): relation avec les changements climatiques au cours des 60,000 dernières années. Bulletin of the Society Géologie France, 165, 613621.

Thouveny, N., Creer, K.M. and Blunk, I. (1990). Extention of the lac du bouchet palaeomagnetic record over the last 120,000 years. Earth and Planetary Science Letters, 97, 140161.
Thouveny, N., Beaulieu J.L. de, Bonifay, E., Creer, K.M., Guiot, L, Icole, M., Johnsen, S., Jouzel, L, Reille, M., Williams, T. and Williamson, D. (1994). Climate variations in Europe over the past $140 \mathrm{kyr}$ deduced from rock magnetism. Nature, 371, 503-506.

Truze, E. (1990): Etudes sédimentologiques et géochimiques des dépôts du maar du Bouchet (Massif central, France). Evolution d'un système lacustre au cours du dernier cycle climatique. Ph.D. (Thése de doctorat en Sciences, Univ. AixMarseille II). $242 \mathrm{pp}$. 